tions have been completed (Stebich et al., 2009), and b) the late Holocene with geochemical (Schettler et al., 2006b) and minerogenic analyses (Chu et al., 2009). For the late Glacial in particular, short cold/ dry spells were recorded that are perfectly correlated with events reported from the Greenland ice core records. Such synchronicity in abrupt climate shifts demonstrates that the North Atlantic and East Asian regions were strongly coupled via atmospheric teleconnections. The varvebased chronologies that have been established from several lakes also enabled precise determination of the age of several tephra layers preserved in the sediment records, thereby providing a much improved chronology of volcanic eruptions in northeastern China (Liu et al., 2009).

\section{Outlook}

In addition to the research topics outlined above, lake sediment records are also used to investigate the history of eutrophication, especially in the large and shallow floodplain lakes of the middle and lower reaches of the Yangtze River, which is one of the most densely populated and industrialized areas in China. Paleolimnological research on these lakes mainly relies upon diatom-based reconstructions of total phosphorus concentrations in lake water (Yang et al., 2008; Dong et al., 2008). The multi-proxy record from Lake Erhai in Yunnan, southern China, is also an excellent example of how to use lake sediment records to reconstruct climate-human-environment interactions during the Holocene (Dearing et al., 2008).

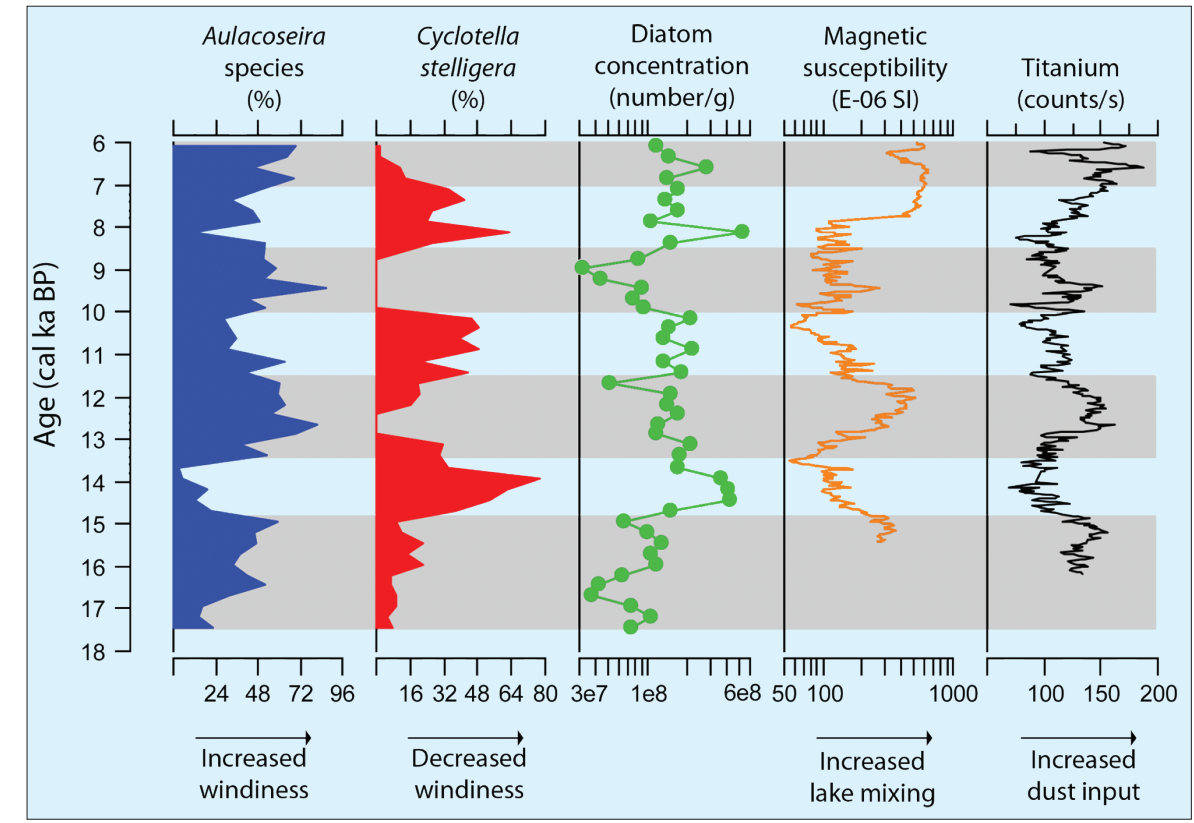

Figure 2: Comparison of the diatom data: \% abundances of the planktonic centric taxa Aulacoseira spp. (blue) and Cyclotella stelligera (red), as well as diatom concentration (green) (Wang et al., 2008), with the titanium (Ti) content (black) and magnetic susceptibility records (orange) (Yancheva et al., 2007) from the Huguang maar lake (South China). High abundances of Aulacoseira spp. are indicative of periods of turbulent water column mixing due to strong winds, while increased abundance of $C$. stelligera suggests thermally stratified, weak wind conditions. The seasonal change in relative abundance of these taxa can, therefore, be used as a proxy of the strength of winter monsoon winds. Ti and magnetic susceptibility are proxies for dust input and lake mixing, respectively.

\section{Acknowledgements}

The authors would like to thank the financial support from the National Science Foundation of China (grants \# 4050 21018, 40872113 and 10572107) and the Chinese Academy of Sciences (grant \# kzcx2-yw-119-02).

\section{References}

Chen, F. et al., 2008: Holocene moisture evolution in arid central Asia and its out-of-phase relationship with Asian monsoon history, Quaternary Science Reviews, 27: 351-364.

Chu, G., Sun, Q., Gu, Z., Rioual, P., Liu, Q., Wang, K., Han, J. and Liu, J., 2009: Dust records from varved lacustrine sediments of two neighboring lakes in northeastern China over the last 1400 years, Quaternary International, 194: 108-118.
Colman, S.M., Yu, S.-Y., An, Z.S., Shen, J. and Henderson, A.C.G., 2007 Late Cenozoic climate changes in China's western interior: a review of research on Lake Qinghai and comparison with other records, Quaternary Science Reviews, 26: 2281-2300.

Wang, L. et al., 2008: Diatom-based inference of variations in the strength of Asian winter monsoon winds between 17,500 and 6000 calendar years B.P., Journal of Geophysical Research, 113. D21101, doi:10.1029/2008JD010145.

Yancheva, G. et al., 2007: Influence of the intertropical convergence zone on the East Asian monsoon, Nature, 445: 74-77.

For full references please consult:

www.pages-igbp.org/products/newsletters/ref2009_3.html

\title{
Paleolimnology of African lakes: Beyond the exploration
} \section{phase}

Dirk Verschuren ${ }^{1}$ and James M. Russell ${ }^{2}$

'Limnology Unit, Department of Biology, Ghent University, Belgium; dirk.verschuren@UGent.be Department of Geological Sciences, Brown University, Providence, USA

\section{Longstanding research questions on tropical climate-human-ecosystem interactions can be tackled by combining novel and traditional paleoenvironmental proxies from high-quality sediment archives in African lakes.}

\section{Paleolimnology of African lakes: Something particular}

African lakes have had a special allure to paleolimnologists ever since pioneering work by Dan Livingstone and his students revealed their potential for tropical paleoecology and paleoclimatology. However, it took time before their particularities (e.g., methane-charged muds, unstable sedimentary environments associated with fluctuating lake level) and logistical chal- lenges no longer hampered application of the modern paleolimnological techniques that were developed in Europe and North America during the 1980s. Given the scarcity of annually resolved African lake records, progress in African paleolimnology depends on well-constrained radiometric chronologies. This is often challenging, because lakes with the hydrological sensitivity required to register decade- to century-scale climate variability tend to display significant variability in sedimentation rates and radiocarbon reservoir age, with complicating effects on the agedepth relationship that cannot easily be resolved by ${ }^{210} \mathrm{~Pb} /{ }^{14} \mathrm{C}$-based age models. As for the reconstructions themselves, the principal issues are that, firstly, past human impacts on African lakes and the surrounding landscapes cannot be determined without accounting for major climatic influence on ecosystem dynamics at 
all timescales; and secondly, the pressing need for quantitative temperature proxies, and for hydrological proxies unaffected by lake-groundwater interactions and temperature effects on evaporation. Basinspecific hydrological modeling is one solution, exemplified by work on Rift Valley lakes in Ethiopia (Legesse et al., 2004) and Kenya (Bergner et al., 2003; Duhnforth et al., 2006). Other methodological advances have come from the development of regional calibration datasets that constrain the ecological indicator value of in-lake biological proxies (e.g., Rumes et al., 2005; Eggermont et al., 2006; 2009), and application of new organic biomarker proxies for temperature and moisture balance to African lake records.

\section{Resolving African climate history}

Reconstructions of African climate history using these improved techniques testify to the global teleconnection of climate variability at glacial-interglacial, orbital and shorter time scales but also reveal distinct tropical climate processes. For example, results of ICDP-sponsored drilling in Lake Malawi (southeastern tropical Africa) and Lake Bosumtwi (tropical West Africa) show that tropical African climate history differs from the characteristic 100-ka saw-tooth pattern of continental ice-sheet growth and decay. Most importantly, tropical aridity during the Last Glacial Maximum (MIS2) paled in comparison with megadroughts recurring at $\sim 21$-ka intervals during MIS5 and MIS4, when high eccentricity strengthened precessional insolation forcing (Scholz et al., 2007; Cohen et al., 2007). Penetrating a sub-lacustrine ridge in Lake Tanganyika with Kullenbergcoring methods, Felton et al. (2007) recovered a continuous climate record back to the base of MIS3. Analyses of organic biomarker proxies for past temperature (the TEX ${ }_{86}$ index of crenarchaeotal membrane lipids) and moisture balance (the $\delta D$ of leaf waxes) by Tierney et al. (2008) revealed that millennial MIS3 drought episodes in southeastern tropical Africa coincide with Heinrich events (Fig. 1), suggesting northern high-latitude influence on sea-surface temperature in the western Indian Ocean. This study also confirmed the result of Powers et al. (2005) from Lake Malawi, which showed that postglacial warming started $\sim 20 \mathrm{ka} \mathrm{BP}$, i.e., coincident with the start of major continental icesheet melting, but well before the rise in atmospheric $\mathrm{CO}_{2}$. A moisture balance reconstruction from Lake Malawi based on the $\mathrm{C} 3 / \mathrm{C} 4$ vegetation ratio incorporated in the $\delta^{13} \mathrm{C}$ of leaf wax alkanes (Castañeda et al., 2007) supports evidence for early
Holocene drought in southern tropical Africa (Nash et al., 2006; Garcin et al., 2007), associated with the rapid resumption of Intertropical Convergence Zone (ITCZ) migration far into the Northern Hemisphere at the end of the Younger Dryas (Talbot et al., 2007). Reviewing all relevant lake (and nearshore marine) paleoclimate records/ patterns across southern Africa, Gasse et al. (2008) report progress in resolving the longstanding conflict between evidence for a dry LGM (and Younger Dryas) in Lake Malawi (e.g., Johnson et al., 2002) vs. wet conditions during those times recorded in nearby Lake Masoko (Garcin et al., 2006). Another issue of longstanding debate has been whether Holocene retreat of the northernmost summer-time position of the ITCZ caused a gradual or abrupt midHolocene weakening of the West African monsoon over North Africa, and thus a gradual or abrupt mid-Holocene desiccation of the Sahara desert. Multiple-proxy analyses on the uniquely continuous sediment record of a groundwater-fed lake in northern Chad (Kröpelin et al., 2008) revealed that, while the aquatic ecosystem responded to deteriorating moisture balance with a threshold response to hydrological closure of the lake basin, the surrounding terrestrial ecosystem evolved gradually from a grass savannah to Sahe- lian scrubland to hyper-arid desert, between 5.6 and $2.7 \mathrm{ka}$.

Until recently, reconstructions of Holocene climate history in sub-Saharan Africa showed affinity with either Northern or Southern Hemisphere summer insolation forcing. A new 25-ka lake record from Lake Challa near Mt. Kilimanjaro, just south of the equator in East Africa, promises to reveal the history of hydrological change in the western Indian Ocean domain, where latitudinal ITCZ migration far north and south of the equator generates a markedly bimodal pattern of seasonal rainfall (Verschuren et al., ESF EuroCLIMATE project CHALLACEA). However, because the north-south trending Congo Air Boundary, where moisture from the Atlantic and Indian Ocean meet, is situated near 33$35^{\circ} \mathrm{E}$ above the East African plateau, the climate history of much of tropical Africa bears a strong signature of variation in Atlantic Ocean circulation. This is particularly evident during the main phase of the Little Ice Age (LIA; 1400-1750 AD), when drought in western tropical Africa (Shanahan et al., 2009) and central equatorial Africa including western portions of the East African plateau (e.g, Russell and Johnson, 2007) contrasted with above-average rainfall over the eastern half of the plateau (Verschuren et al. 2000a). Lake Victoria

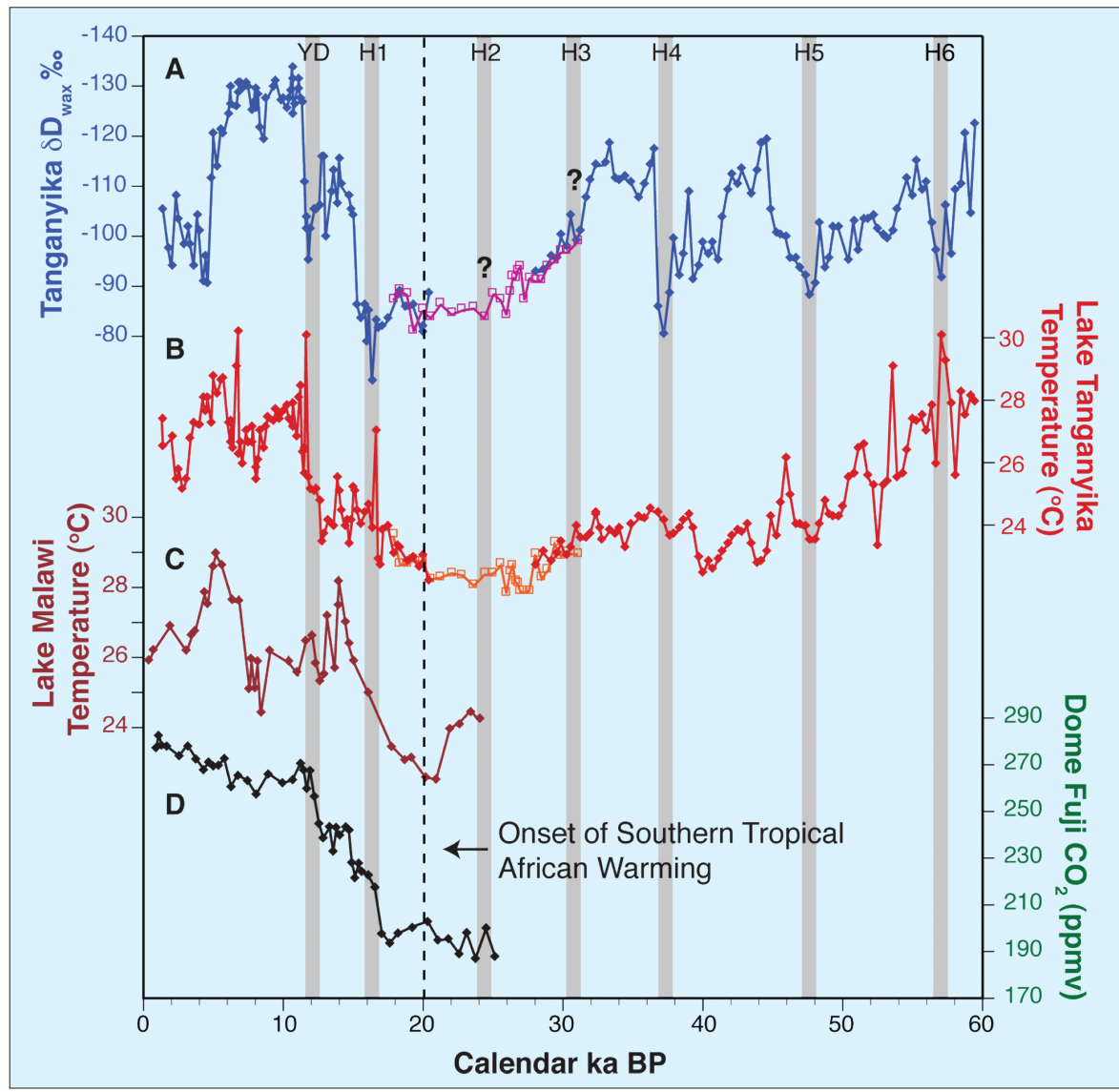

Figure 1: Comparison of Lake Tanganyika $\delta D$-inferred regional moisture balance (A; blue and purple lines) and TEX $X_{86}$-inferred temperature (B; red and orange lines) with the Lake Malawi TEX ${ }_{86}$-inferred temperature ( $\boldsymbol{C}$; brown line; Powers et al., 2005), and glacial-to-Holocene record of atmospheric $\mathrm{CO}_{2}$ in Dome Fuji ice (D; black line; Kawamura et al., 2007). Gray bars indicate the Younger Dryas (YD) and Heinrich events $\mathrm{H} 1$ to $\mathrm{H6}$; $\mathrm{H} 2$ and $\mathrm{H} 3$ are not apparent in Tanganyika basin hydrology. Figure modified after Tierney et al. (2008). 

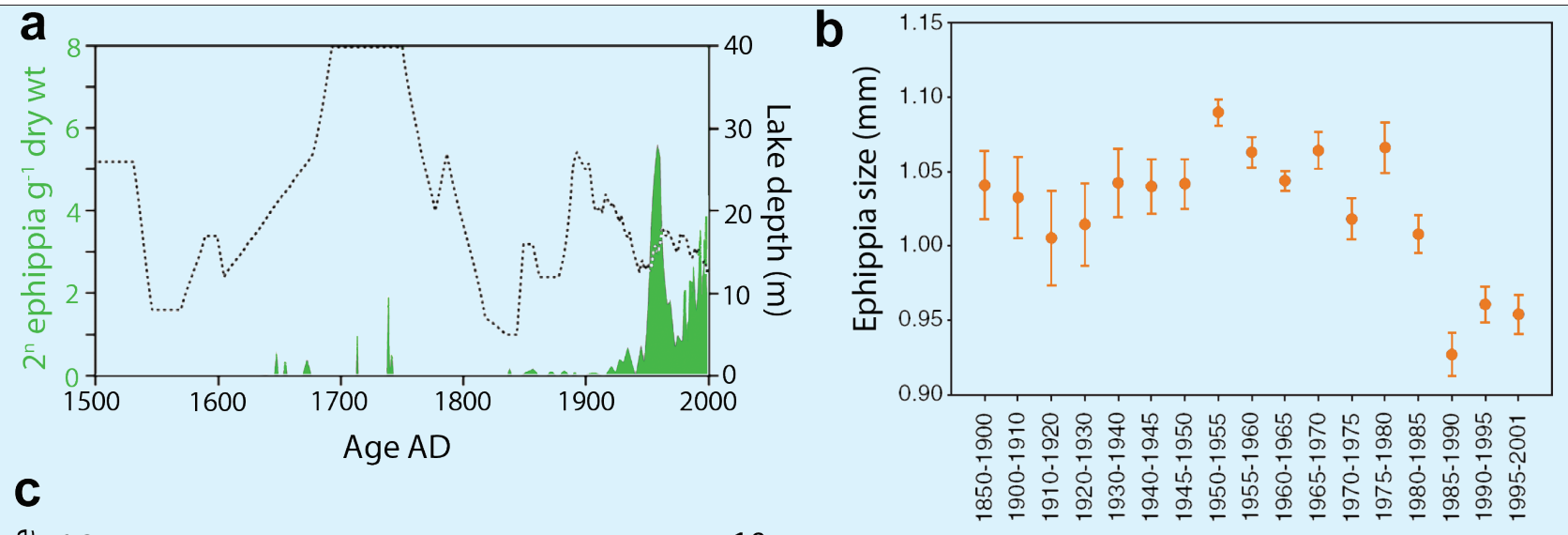

C
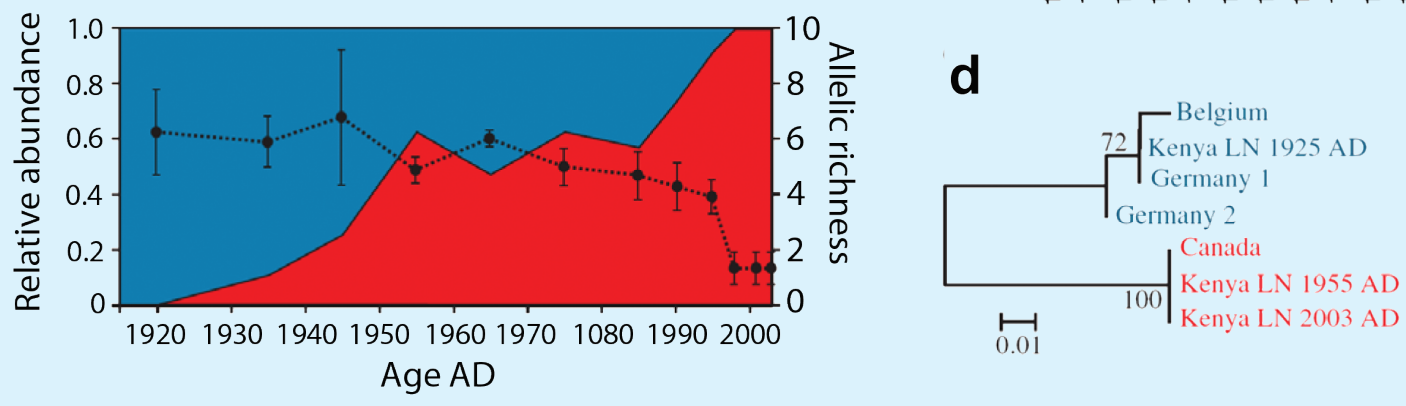

e

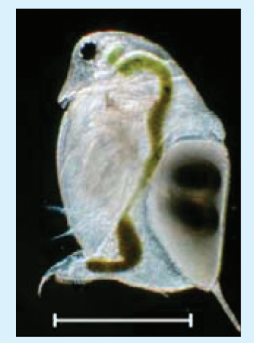

Fiqure 2: History of the water flea Daphnia pulex population in Lake Naivasha (Kenya) reconstructed from the sediment record of its fossil resting egas (ephippia). a) Population abundance through time (green area) in relation to historical lake-level fluctuations (dotted line), showing the relative scarcity of this species prior to the 1940s. $2^{n}=$ ephippia abundance on base 2 logarithmic scale. $\boldsymbol{b})$ Evolution of mean water-flea body size since the mid-1 $9^{\text {th }}$ century derived from measurements of fossil ephippia. This indicates i) lowered size-selective fish predation in the 1950 s due to fishery collapse associated with the mid-20 $0^{\text {th }}$-century lowstand, and ii) recently increasing fish predation attributed to the disappearance of submerged aquatic macrophytes, which has resulted from anthropogenic siltation and eutrophication. c) Relative abundance of the asexual American genotype (red) and the indigenous African genotypes (blue) of D. pulex in Lake Naivasha since the inadvertent introduction of the American D. pulex variant during a fish-stocking effort in the 1920s, based on genetic analysis of multiple individual fossil ephippia in each sediment level; also shown is the associated loss in the local population's genetic diversity through time (allelic richness: dotted line with 95\% confidence intervals). d) Phylogenetic tree based on a mitochondrial gene fragment showing the relationship of Lake Naivasha D. pulex in 1925, 1955 and 2003 to populations from Belgium and Germany ('Old World' genotypes, including Africa) and Canada ('New World' genotypes). The scale bar indicates genetic distance, i.e., the number of base substitutions between the different gene variants (haplotypes). e) D. pulex with eggs visible inside the ephippium. The scale bar is $1 \mathrm{~mm}$. Figures a, c and d are from Mergeay et al. (2006), b is from Mergeay et al. (2004).

(Stager et al., 2005) and central Ethiopia (Lamb et al., 2007) display intermediate LIA rainfall anomalies, reminiscent of the regional patterns of modern ENSO teleconnections (Verschuren and Charman, 2008).

\section{Resolving human impact on African ecosystems}

Lake Tanganyika, buffered against the immediate impact of catchment disturbance by great depth and permanent stratification, produced the first paleolimnological evidence of African lake-ecosystem response to anthropogenic climate change (O'Reilly et al., 2003). This would be much harder to demonstrate in records from shallower African lakes, of which the aquatic communities show continuous species turnover due to habitat restructuring associated with lake-level and salinity fluctuations (Verschuren et al., 1999; 2000b). Paleolimnological studies on the population genetics of water fleas in such lakes show that their genotypic identity is stable through time as long as episodes of ecological crisis (such as lake desiccation) do not exceed the few decades during which resting eggs remain viable in bottom muds (Mergeay et al., 2007). Another paleogenetic study (Mergeay et al., 2006) revealed that an asexual American variant of the common water flea Daphnia pulex, introduced accidentally to Lake Naivasha in Kenya in the 1920s, has since outcompeted the indigenous, sexually reproducing variant of the same species not only locally, but throughout sub-Saharan Africa (Fig. 2).

\section{Outlook of paleolimnology in African lakes}

With the spatial patterns of past hydrological change across tropical Africa now better constrained, studies of climate-human-environment interactions can start to make rigorous distinction between climate-driven and anthropogenic impacts on the long-term dynamics of vegetation, fire and lake-water quality. Although today's profound landscape modification has mostly resulted from rapidly increasing demographic and agricultural pressure during the $20^{\text {th }}$ century (Verschuren et al., 2002; Fleitmann et al., 2007), significant vegetation disturbance by indigenous agriculturalists extends to the late $18^{\text {th }}$ century near Lake Tanganyika (Cohen et al., 2005), the $17^{\text {th }}$ century in the Kenya highlands (Lamb et al., 2003), and at least the $10-11^{\text {th }}$ century in western Uganda (Ssemmanda et al., 2005; Lejju, 2009; Russell et al., 2009). In western tropical Africa, landscape disturbance is thought to have started $\sim 2400$ BP when climate-induced drying opened up the rainforest for farming (Ngomanda et al., 2009). Future studies will paint an increasingly comprehensive picture of the timing and relative magnitude of indigenous human impact on the African landscape. Focusing on the highest-quality lake-sediment records and through innovative use of both traditional and novel proxies, African paleolimnology will no doubt continue to make significant contributions to our understanding of past tropical climate dynamics and climate-human-ecosystem interaction.

\section{References}

Gasse, F., Chalié, F., Vincens, A., Williams, M.A.J. and Williamson, D., 2008: Climatic patterns in equatorial and southern Africa from 30,000 to 10,000 years ago reconstructed from terrestrial and near-shore proxy data, Quaternary Science Reviews, 27: 23162340.

Kröpelin, S. et al., 2008: Climate-driven ecosystem succession in the Sahara: the past 6000 years, Science, 320: 765-768.

Mergeay, J., Verschuren, D. and De Meester, L., 2006: Invasion of an asexual American water flea clone throughout Africa and rapid displacement of a native sibling species, Proceedings of the Royal Society London B, 273: 2839-2844

Scholz, C.A., et al., 2007: East African mega-droughts between 135 and 75 thousand years ago and bearing on early-modern human origins, Proceedings of the National Academy of Scienes USA, 104: 16416-16421.

Tierney, J.E., Russell, J.M., Huang, Y.S. and Cohen, A.S., 2008: Northern Hemisphere controls on tropical Southeast African climate during the last 60,000 years, Science, 322: 252-255.

For full references please consult:

www.pages-igbp.org/products/newsletters/ref2009_3.html 


\section{Full Reference List:}

Bergner, A.G.N., Trauth, M.H. and Bookbagen, B., 2003: Paleoprecipitation estimates for the Lake Naivasha basin (Kenya) during the last 175 ky using a lake-balance model, Global and Planetary Change, 36: 117136.

Castañeda, I.S., Werne, J.P. and Johnson, T.C., 2007: Wet/arid phases in the southeast African tropics since the Last Glacial Maximum, Geology, 35, 823-826.

Cohen, A.S., Palacios-Fest, M.R., Msaky, E.S., Alin, S.R., McKee, B.A., O'Reilly, C.M., Dettman, D.L., Nkotagu, H., and Lezzar, K.E., 2005: Paleolimnological investigations of anthropogenic environmental change in Lake Tanganyika: IX. Summary of paleorecords of environmental change and catchment deforestation at Lake Tanganyika and impacts on the Lake Tanganyika ecosystem, Journal of Paleolimnology, 34: 125145.

Cohen, A.S, et al., 2007: Ecological consequences of early Late Pleistocene mega-droughts in tropical Africa, Proceedings of the National Academy of Science USA, 104: 16422-16427.

Duhnforth, M., Bergner, A.G.N. and Trauth, M.H., 2006: Early holocene water budget of the Nakuru-Elmenteita Basin, Central Kenya Rift, Journal of Paleolimnology, 36: 281-294.

Eggermont, H., Heiri, O. M., Russell, J. M., Vuille, M., Audenaert, L. and Verschuren, D., 2009: Paleotemperature reconstruction in tropical Africa using fossil Chironomidae (Insecta: Diptera), Journal of Paleolimnology, doi 10.1007/s10933-009-9339-2.

Eggermont, H., Heiri, O. M. and Verschuren, D., 2006: Subfossil Chironomidae (Insecta: Diptera) as quantitative indicators of past salinity variation in African lakes, Quaternary Science Reviews, 25: 1966-1994.

Felton, A.A., et al., 2007: Paleolimnological evidence for the onset and termination of glacial aridity from Lake Tanganyika, Tropical East Africa, Palaeogeography, Palaeoclimatology, Palaeoecology, 252: 405-423.

Fleitmann, D., Dunbar, R.B., McCulloch, M., Mudelsee, M., Vuille, M., McClanahan, T., Andrews, C. and Mucciarone, D.A., 2007: East African soil erosion recorded in a 300-year old coral colony from Kenya, Geophysical Research Letters, 34: L04401.

Garcin, Y., Vincens, A., Williamson, D., Guiot, J. and Buchet, G., 2006: Wet phases in tropical southern Africa during the last glacial period, Geophysical Research Letters, 33: L07703.

Garcin, Y., Vincens, A., Williamson, D., Buchet, G. and Guiot, J., 2007: Abrupt resumption of the African Monsoon at the Younger Dryas-Holocene climatic transition, Quaternary Science Reviews, 26: 690-704.

Gasse, F., Chalié, F., Vincens, A., Williams, M.A.J. and Williamson, D., 2008: Climatic patterns in equatorial and southern Africa from 30,000 to 10,000 years ago reconstructed from terrestrial and near-shore proxy data, Quaternary Science Reviews, 27: 2316-2340.

Johnson, T.C., Brown, E.T., McManus, J., Barry, S., Barker, P. and Gasse, F., 2002: A high-resolution paleoclimate record spanning the past 25,000 years in southern East Africa, Science, 296: 113-116.

Kawamura, K. et al., 2007: Northern hemisphere forcing of climatic cycles in Antarctica over the past 360,000 years, Nature, 448: 912-916.

Kröpelin, S. et al., 2008: Climate-driven ecosystem succession in the Sahara: the past 6000 years, Science, 320 : 765-768.

Lamb, H., Darbyshire, L. and Verschuren, D., 2003: Vegetation response to rainfall variation and human impact in central Kenya during the past 1100 years, The Holocene, 13: 285-292.

Lamb, H.F., Leng, M.J., Telford, R.J., Ayenew, T. and Umer, M., 2007. Oxygen and carbon isotope, composition of authigenic carbonate from an Ethiopian lake: a climate record of the last 2000 years, The Holocene, 17, 517-526.

Legesse, D., Vallet-Coulomb, C. and Gasse, F., 2004: Analysis of the hydrological response of a tropical terminal lake, Lake Abiyata (Main Ethiopian Rift Valley) to changes in climate and human activities, Hydrological Processes, 18, 487-504.

Lejju, J.B., 2009: Vegetation dynamics in western Uganda during the last 1000 years: climate change or human induced environmental degradation? African Journal of Ecology, 47: 21-29.

Mergeay, J., Verschuren, D., Van Kerckhoven, L. and De Meester, L., 2004: Two hundred years of a diverse Daphnia community in Lake Naivasha (Kenya): effects of natural and human-induced environmental changes, Freshwater Biology, 49: 998-1013.

Mergeay, J., Verschuren, D. and De Meester, L., 2006: Invasion of an asexual American water flea clone throughout Africa and rapid displacement of a native sibling species, Proceedings of the Royal Society London B, 273: 2839-2844.

Mergeay, J., Vanoverbeke, J., Verschuren, D. and De Meester, L., 2007: Extinction, re-colonization, and dispersal through time in a planktonic crustacean, Ecology, 88: 3032-3043. 
Nash, D.J., Meadows, M.E. and Gulliver, V.L., 2006: Holocene environmental change in the Okavango Panhandle, northwest Botswana, Quaternary Science Reviews, 25: 1302-1322.

Ngomanda, A., Neumann, K., Schweizer, A. and Maley, J., 2009: Seasonality change and the third millennium BP rainforest crisis in southern Cameroon (Central Africa), Quaternary Research, 71: 307-318.

O'Reilly, C.M., Alin, S.R., Plisnier, P.D., Cohen, A.S. and McKee, B.A., 2003: Climate change decreases aquatic ecosystem productivity of Lake Tanganyika, Africa, Nature, 424: 766-768.

Powers, L. A., Johnson, T.C., Werne, J.P., Castañeda, I.S., Hopmans, E.F., Sinninghe Damsté, J.S. and Schouten, S., 2005: Large temperature variability in the southern African tropics since the Last Glacial Maximum, Geophysical Research Letters, 32: L08706.

Rumes, B., Eggermont, H. and Verschuren, D., 2005: Subfossil representation of aquatic invertebrate communities in a salinity gradient of western Uganda crater lakes, Hydrobiologia, 542: 297-314.

Russell, J.M. and Johnson, T.C., 2007. Little Ice Age drought in equatorial Africa: ITCZ migrations and ENSO variability, Geology, 35: 21-24.

Russell, J.M., McCoy S.J., Verschuren, D., Bessems, I., Blaauw, M. and Huang, Y., 2009: Human impacts, climate change, and aquatic ecosystem response during the past 2,000 years at Lake Wandakara, Uganda, Quaternary Research, doi 10.1016/j.yqres.2009.06.008.

Scholz, C.A., et al., 2007: East African mega-droughts between 135 and 75 thousand years ago and bearing on early-modern human origins, Proceedings of the National Academy of Scienes USA, 104: 16416-16421.

Ssemmanda, I., Ryves, D.B., Bennike, O. and Appleby, P.G., 2005: Vegetation history in western Uganda during the last 1200 years: a sediment-based reconstruction from two crater lakes, The Holocene, 15: 119-132.

Shanahan, T.M., Overpeck, J.T., Anchukaitis, K.J., Beck, J.W., Cole, J.E., Dettman, D.L., Peck, J.A., Scholz, C.A. and King, J.W., 2009: Atlantic forcing of persistent drought in West Africa, Science, 324: 377-380.

Stager, J.C., Ryves, D., Cumming, B.F., Meeker, L.D. and Beer, J., 2005: Solar variability and the levels of Lake Victoria, East Africa, during the last millennium, Journal of Paleolimnology, 33: 243-251.

Talbot, M.R., Filippi, M.L., Jensen, N.B. and Tiercelin, J.-J., 2007: An abrupt change in the African monsoon at the end of the Younger Dryas, Geochemistry, Geophysics, Geosystems, 8: Q03005.

Tierney, J.E., Russell, J.M., Huang, Y.S. and Cohen, A.S., 2008: Northern Hemisphere controls on tropical Southeast African climate during the last 60,000 years, Science, 322: 252-255.

Verschuren, D. and Charman, D., 2008: Latitudinal linkages in late-Holocene moisture-balance variation. In: Battarbee, R.W. et al. (Eds), Natural climate variability and global warming, Blackwell, 189-231.

Verschuren, D., Tibby, J., Leavitt, P.R. and Roberts, C.N., 1999: The environmental history of a climate-sensitive lake in the former 'White Highlands' of central Kenya, Ambio, 28: 494-501.

Verschuren, D., Laird, K.R. and Cumming, B.F., 2000a: Rainfall and drought in equatorial East Africa during the past 1100 years, Nature, 403: 410-414.

Verschuren, D., Tibby, J., Sabbe, K. and Roberts, N., 2000b: Effects of lake level, salinity and substrate on the invertebrate community of a fluctuating tropical lake, Ecology 81: 164-182.

Verschuren, D., Johnson, T.C., Kling, H.J., Edgington, D.N., Leavitt, P.R., Brown, E.T., Talbot, M.R. and Hecky, R.E., 2002: History and timing of human impact on Lake Victoria, East Africa, Proceedings of the Royal Society London B, 269: 289-294. 